\title{
PENGEMBANGAN MULTIMEDIA INTERAKTIF PADA PEMBELAJARAN IPA BAGI SISWA SEKOLAH DASAR KOTA LUBUKLINGGAU
}

\author{
Asep Sukenda Egok ${ }^{1}$, Tri Juli Hajani ${ }^{2}$ \\ STKIP-PGRI Lubuklinggau ${ }^{1,2}$ \\ asep.egok91@gmail.com ${ }^{1}$
}

\begin{abstract}
ABSTRAK
Penelitian ini bertujuan untuk menghasilkan Multimedia Interaktif pada pembelajaran IPA yang valid, praktis dan memiliki efek potensial terhadap hasil belajar siswa kelas V di SD Kota Lubuklinggau. Prosedur penelitian menggunakan model Rowntree yang memiliki tiga tahap, yaitu: perencanaan, pengembangan, dan evaluasi. Evaluasi yang digunakan adalah evaluasi formatif Tessmer. Hasil penelitian dari validasi aspek materi, media, dan desain pembelajaran menunjukkan bahwa multimedia interaktif ini valid. Pada tahap uji one-to-one, siswa yang dijadikan subjek penelitian memberikan respon sangat baik terhadap multimedia interaktif yang digunakan. Pada tahap uji coba small group dengan kategori praktis. Pada tahap field test dengan skor 79,11 dalam kategori sedang. Berdasarkan hasil penelitian dapat disimpulkan bahwa multimedia interaktif yang dikembangkan dalam penelitian ini terbukti valid, praktis, dan memiliki efek potensial terhadap hasil belajar siswa dalam pembelajaran IPA di Sekolah Dasar.
\end{abstract}

Kata Kunci: Multimedia Interaktif, Pembelajaran IPA

\section{ABSTRACT}

The study aims at producing the valid, practical, interactive and potential multimedia to teach science to students achievement at the fifth grade elementary school in Lubuklinggau. The procedure of the study was through Rowntree model including three steps, namely planning, developing and evaluation. The evaluation stepnm used was Tessmer formative evaluation. The result of the material, media and design validation showed that interactive multimedia was valid. In one-to-one test, the students respond positively toward the interactive multimedia. In tryout step on the small group, it categorized as practical. In the field test, it was categorised as medium with score 79,11. It can be concluded that interactive multimedia was developed in the study was valid, practical and potential on students science learning achievement at the Elementary School.

Keywords: interactive multimedia, science learning 


\section{PENDAHULUAN}

Dalam perkembangan dibidang teknologi informasi, pemanfaatan dalam dunia pendidikan sangat mendukung dalam proses pembelajaran, salah satunya multimedia interaktif. Multimedia merupakan produk dari kemajuan teknologi digital. Multimedia dapat menampilkan pesan dan pengetahuan dalam bentuk gabungan atau kombinasi antara beberapa unsur seperti: teks, audio, grafis, video dan animasi secara simultan. Pada pembelajaran IPA, dapat digunakan media pembelajaran yang mengintegrasikan: teks, gambar, serta suara dan video secara bersamaan, sehingga pembelajaran IPA akan terasa menarik, efektif dan efisien. Arsyad, Azhar. (2009), mengemukakan bahwa terdapat beberapa jenis media pembelajaran yang digunakan oleh guru, instruktur dan perancang program pembelajaran, yaitu: (1) media cetak/teks; (2) media pameran/display; (3) media audio; (4) gambar bergerak atau motion pictures; (5) multimedia; dan (6) media berbasis web atau internet.

Pembelajaran IPA sebaiknya dilaksanakan secara inkuiri ilmiah (scientific inquiry) agar dapat menumbuhkan kemampuan berpikir (B.R. Seels. 2009). Pada kurikulum IPA Sekolah Dasar terdapat ruang lingkup bahan kajian yang meliputi aspek-aspek: (1) makhluk hidup dan proses kehidupan, yaitu: manusia, hewan, tumbuhan dan interaksinya dengan lingkungan serta kesehatan; (2) benda/materi, sifat-sifat kegunaannya meliputi benda cair, padat dan gas; (3) energi dan perubahannya meliputi: gaya, bunyi, panas, magnet, listrik, cahaya dan pesawat sederhana; dan (4) bumi dan alam semesta meliputi; tanah, bumi, tata surya dan benda-benda langit. Dari beberapa ruang lingkup bahan kajian materi di atas sangat cocok untuk menggunakan pengembangan multimedia interaktif.

Berdasarkan hasil studi pendahuluan melalui wawancara dengan guru IPA kelas 5 SD Kota Lubuklinggau, pada pembelajaran IPA dalam materi penyesuaian diri makhluk hidup dengan lingkungannya masih mengalami beberapa hambatan. Untuk membentuk suatu proses pembelajaran yang ideal maka harus berpusat pada siswa (student centered), yaitu siswa dituntut aktif dalam proses pembelajaran. Akan tetapi, kenyataan yang terjadi di lapangan adalah guru masih menjadi pusat belajar (teacher centered) bagi siswa. Selain itu, keadaan ini juga disebabkan oleh cara mengajar guru yang sering menggunakan metode ceramah, text book centered dan jarang menggunakan media pembelajaran. Siswa membutuhkan penjelasan dari guru dalam bentuk nyata, akan tetapi karena guru tidak menggunakan media pembelajaran yang dapat menarik minat siswa dalam belajar, maka hasil belajar siswa belum maksimal. Selain itu, guru juga belum menggunakan media pembelajaran berupa benda konkrit, gambar ataupun video sehingga siswa tidak dapat mengamati secara langsung.

Hambatan-hambatan lain yang dialami oleh guru dan siswa dalam proses pembelajaran adalah siswa belum terbiasa belajar mandiri dan menganggap bahwa guru merupakan sumber ilmu yang mengakibatkan kurangnya persiapan siswa sebelum pembelajaran dimulai. Guru telah berupaya untuk menciptakan lingkungan belajar yang dapat mendorong pengembangan potensi siswa, hanya saja tingkat pemanfaatan potensi dan peluang sumber-sumber belajar belum maksimal, seperti belum menggunakan LAB komputer di sekolah yang sudah terkoneksi dengan jaringan internet. Selain itu, guru belum dapat mengoptimalkan pembelajaran berbantuan Information and Communication (ICT) sehingga bahan belajar serta pengetahuan siswa masih terbatas pada buku teks pelajaran dan 
pengetahuan yang diberikan oleh guru. Model pembelajaran yang digunakan guru juga kurang memberikan kesempatan bagi peserta didik untuk dapat mengembangkan keterampilan berpikir. Materi pembelajaran IPA yang melibatkan benda kongkret dan lingkungan jika hanya menggunakan media sederhana berupa gambar-gambar saja, peserta didik akan sulit memahami materi yang diajarkan (Campbell, Reece and Mitchell. 2000).

Penggunaan multimedia interaktif dalam pembelajaran diharapkan dapat membantu memberikan pengalaman yang bermakna kepada siswa, karena penggunaan multimedia interaktif ini dapat mempermudah siswa dalam memahami sesuatu yang abstrak menjadi lebih konkrit. Pengalaman belajar anak mulai dari hal-hal yang paling konkrit sampai kepada hal-hal yang dianggap paling abstrak, dimulai dari siswa yang berpartisipasi dalam pengalaman nyata, kemudian menuju siswa sebagai pengamat kejadian nyata, dilanjutkan ke siswa sebagai pengamat terhadap kejadian yang disajikan dengan media dan terakhir siswa sebagai pengamat kejadian yang disajikan dengan simbol. Hal tersebut sejalan dengan hasil penelitian Fathan, F. (2011) dan Walton (1993) dalam Sidhu (2010: 24), pemanfaatan multimedia dalam Pujawan, K.A.H. (2014), pembelajaran dapat meningkatkan hasil belajar 56\% lebih besar, konsistensi dalam belajar 50-60\% lebih baik dan ketahanan dalam memori $25-50 \%$ lebih tinggi.

Setiawan, Denny. (2001), mengemukakan bahwa sistem multimedia mempunyai beberapa keuntungan, yaitu: (1) mengurangi waktu dan ruang yang digunakan untuk menyimpan dan menampilkan dokumen dalam bentuk elektronik dibanding dalam bentuk kertas; (2) meningkatkan produktivitas dengan menghindari hilangnya file; (3) memberi akses dokumen dalam waktu bersamaan dan ditampilkan dalam layar; (4) memberi informasi multidimensi dalam organisasi; (5) mengurangi waktu dan biaya dalam pembuatan foto; dan (6) memberikan fasilitas kecepatan informasi yang diperlukan dengan int eraksi visual. Selain itu, manfaat multimedia adalah memungkinkan dialog, meningkatkan kreativitas, memfasilitasi kolaborasi, memperkaya pengalaman, dan meningkatkan keterampilan.

Berpijak dari uraian di atas, peneliti tertarik untuk melakukan kegiatan pengembangan media pembelajaran pada mata pelajaran IPA sehingga diharapkan dapat meningkatkan hasil belajar siswa dan memaknai pembelajaran IPA dengan penelitian yang berjudul "Pengembangan Multimedia Interaktif bagi Siswa Sekolah Dasar Kota Lubuklinggau".

\section{METODE PENELITIAN}

Metode yang digunakan dalam penelitian ini adalah research and development. Tujuan utama dalam penelitian ini adalah untuk mengembangkan multimedia interaktif sehingga dapat digunakan oleh siswa Sekolah Dasar dalam pembelajaran IPA di Kota Lubuklinggau. Pengembangan multimedia interaktif dalam penelitian ini mengadaptasi model pengembangan modifikasi Rowntree dan Tessmer. Peneliti memilih model pengembangan ini dikarenakan model dengan pendekatan sistem ini sesuai dengan masalah yang melatarbelakangi penelitian ini (Nasution, 2011)

Dalam mengembangkan multimedia interaktif pada mata pelajaran IPA, peneliti akan menggunakan model Rowntree pada tahap analisis kebutuhan dan 
tahap desain, sedangkan tahap evaluasi akan menggunakan model TESSMER. Adapun langkah-langkah pengembangan multimedia interaktif IPA ini terdiri dari beberapa tahap, yaitu:

Pertama Perencanaan (Planning): pada tahap ini peneliti akan melakukan identifikasi standar kompetensi, kompetensi dasar, perumusan tujuan pembelajaran. Model pengembangan (Development) Rowntree dalam Setiawan (2001: 57) menjelaskan empat (4) tahapan yang perlu dilakukan dalam pengembangan multimedia interaktif, yaitu: 1) mengidentifikasi tujuan instruksional: tujuan instruksional ditulis dengan kalimat yang mengandung aspek ABCD (Audience, Behaviour, Condition, Degree); 2) memformulasikan garis besar materi: materi akan disesuaikan dengan target dan tingkah laku siswa yang diharapkan akan dikuasai setelah belajar menggunakan multimedia interaktif; 3) menulis materi: materi hendaknya memberikan pengetahuan dan keterampilan yang harus dan sebaiknya diketahui siswa serta manfaatnya jika siswa selesai membaca materi tersebut.

Kedua Evaluasi (Evaluation): terdiri dari tahap self evaluation, expert review (review ahli),one-to-one evaluation (evaluasi satu-satu), small group evaluation (evaluasi kelompok kecil)dan field test/uji lapangan (Martin, 1993). Pada tahap ini, dilakukan penilaian sendiri terhadap multimedia interaktif yang dihasilkan, apabila tidak ada kesalahan-kesalahan lagi maka harus dikonsultasikan kepada para ahli yang relevan (expert review) dengan bidangnya untuk mendapatkan masukan (saran) dan kelayakan-kelayakan multimedia interaktif untuk diuji cobakan. Selanjutnya, multimedia interaktif yang telah divalidasi diuji cobakan kepada siswa untuk mendapatkan kepraktisanmultimedia interaktif. Kemudian yang terakhir dilakukan tes untuk mengetahui efek potensial dari penggunaan multimedia interaktif yang dihasilkan. Pada tahap ini, evaluasi menggunakan evaluasi formatif research.

Ketiga Self Evaluation: peneliti akan melakukan penilaian diri sendiri terhadap desain yang telah dibuatnya. Dalam hal ini peneliti menilai desain pengembangan multimedia interaktif IPA.

Keempat Evaluasi Formatif: dalam tahap evaluasi ini desain produk akan diuji cobakan. Ada empat kelompok uji coba ini, yaitu: 1) Review Ahli; 2) Evaluasi Satu-Satu (One to One Evaluation); c) Evaluasi Kelompok Kecil (Small Group Evaluation); 3) Uji Lapangan (Field Test), pada tahap evaluasi, peneliti mengacu pada model evaluasi formatif Tessmer.

Untuk menentukan kualitas hasil pengembangan bahan ajar maka diperlukan tiga kriteria: kevalidan, kepraktisan dan efek potensial. Penelitian ini akan dilaksanakan di tiga sekolah tingkat Sekolah Dasar yang berkategori tinggi, sedang dan rendah yang tersebar di lingkungan Dinas Pendidikan Kota Lubuklinggau. Dengan alasan ketiga sekolah tersebut untuk mewakili seluruh jumlah sekolah tingkat Sekolah Dasar yang tersebar di Kota Lubuklinggau. Dalam penelitian ini yang menjadi subjek penelitian pada saat identifikasi kebutuhan pengembangan multimedia interaktif adalah siswa kelas 5 melalui teknik purposive sampling.

Penelitian ini akan dilaksanakan selama 1 tahun, dari bulan Agustus 2017 sampai dengan bulan Agustus 2018.Adapun teknik pengumpulan data yang digunakan adalahwawancara,digunakan untuk mengumpulkan data berupa opini atau pendapat siswa pada tahap uji satu-satu dan pada tahap studi pendahuluan 
yang diberikan kepada teman sejawat dan peserta didik.Angket, tujuanpenggunaan angket ini adalah untuk mengukur pendapat, persepsi siswa terhadap multimedia interaktif IPA. Angket akan diberikan pada saat kegiatan evaluasi small group.Tes Hasil Belajar, tes digunakan untuk memperoleh data tentang keefektifan atau memiliki potential effect dari perangkat pembelajaran yang dibuat dan mengukur kemampuan peserta didik setelah diberikan pembelajaran dengan menggunakan multimedia interaktif IPA (Martin, Tessmer. 1993). Skor tes yang telah diperoleh masing-masing peserta didik dikonversikan menjadi rentang 0-100.

Analisis data lembar validasi, lembar validasi yang diberikan kepada pakar sebagai validator berbentuk skala likert. Skala Likert yang akan digunakan ada lima kategori yaitu sangat baik (SB), baik (B), cukup (C), tidak baik (TB) dan sangat tidak baik (STB). Hasil validasi dari validator terhadap seluruh aspek yang dinilai akan disajikan dalam bentuk tabel. Selanjutnya dicari rata-rata dan hasil tersebut yang didapat dari perhitungan dikonfirmasi dengan kriteria yang ditetapkan. Rentangan skor mulai dari 0-4 dengan kriteria dibagi menjadi lima tingkatan dan istilah yang digunakan disesuaikan dengan aspek-aspek yang bersangkutan. Kemudian dihitung rerata semua aspek untuk validasi multimedia dalam menentukan tingkat kevalidan multimedia.Selanjutnya uji validitas digunakan untuk mengetahui apakah multimedia interaktifyang dirancang valid atau tidak. Validasi yang akan dilakukan adalah validasi materi/content dan validasi desain pembelajaran. Format lembar validasi dibuat secara sederhana dalam lembar wawancara. Untuk mengetahui kevaliditasan multimedia interaktif IPA yang dikembangkan, maka akan dilakukan validasi para ahli. Setelah mempelajari desain pembelajaran tersebut, ahli akan memberikan komentar dan masukan mengenai desain pembelajaran yang dikembangkan. Data yang diperoleh berupa saran dari para ahli tersebut dijadikan acuan untuk revisi produk sehingga menghasilkan produk yang valid.

Analisis data kuesioner, data tentang respon siswa yang diperoleh dari angket dianalisis menggunakan deskriptif kualitatif, yaitu menggambarkan suatu gejala atau peristiwa yang terjadi sekarang berdasarkan data yang diperoleh dengan bilangan atau angka untuk memperoleh kesimpulan.Dengan memusatkan perhatian terhadap permasalahan yang ada, dengan mencatat, mengukur dan mengklasifikasikan serta dianalisis dengan menghitung frekuensi relatif dalam persen atau tabel presentase.Teknik analisis data dapat digunakan untuk mengolah data yang telah diklasifikasikan menurut fungsi dan jenisnya sesuai dengan tujuan penelitian. Data yang dianalisa tersebut merupakan data hasil angket atau kuesioner yang nantinya akan dihubungkan dengan data wawancara untuk membuat suatu kesimpulan. Sedangkan data yang diperoleh melalui angket akan dianalisa.

Analisis hasil belajar siswa, untuk mengetahui efek potensial penggunaan media pembelajaran multimedia interaktif dilakukan tes hasil belajar. Tes akan dilakukan dari hasil pengumpulan data jawaban dari soal-soal yang diberikan dalam proses pembelajaran. Data hasil belajar yang diperoleh dari hasil penelitian ini akan dianalisis secara deskriptif kualitatif. Data tes yang diperoleh dari hasil jawaban multimedia interaktif berupa soal-soal latihan, PR, pretest dan post test dianalisis untuk mengetahui kategori kemampuan siswa pada saat field test. 
Untuk melihat perbedaan hasil yang didapatkan siswa pada saat pre-test dan post-test digunakan skor gain. N-Gain adalah selisih antara nilai pos-test dan pre-test, gain menunjukkan peningkatan pemahaman atau penguasaan konsep siswa setelah pembelajaran dilakukan guru. Untuk menghindari hasil kesimpulan bias penelitian, karena pada nilai pre-test kedua kelompok penelitian sudah berbeda digunakan uji normalitas. Kelebihan penggunaan model dalam meningkatkan hasil belajar ditinjau berdasarkan perbandingan nilai gain yang dinormalisasi (N-gain), antara kelompok eksperimen dan kelompok kontrol.

\section{HASIL PENELITIAN}

Hasil Analisis Kebutuhan, tujuan penelitian dan pengembangan ini adalah menghasilkan Multimedia Interaktif Pada Pelajaran IPA. Multimedia Interaktif yang dikembangkan ini akan digunakan untuk siswa pada proses pembelajaran IPA SD kelas V pada materi Sistem Organ Makhluk Hidup untuk mempermudah menyampaikan materi yang bersifat abstrak dapat di tampilkan secara audio dan visual.

Langkah yang di lakukan pada pengembangan media ini adalah pertama tahap perencanaan, kedua tahap pengembangan dan ketiga tahap evaluasi, pada tahap pengembangan ini ada tiga hal yang harus dianalisis yaitu (1) analisis kebutuhan, (2) analisis karakteristik peserta didik, dan (3) analisis materi pembelajaran.

Penelitian pendahuluan dilakukan dengan cara pengamatan pada kelas V saat melakukan pembelajaran IPA. Dari pengamatan peneliti bahwa suasana kelas kurang interaktif karena pembelajaran berlangsung masih mengandalkan guru sebagai sumber informasi.Saat menyampaikan materi yang bersifat abstrak hanya dijelaskan secara audio dan gambar yang sangat sederhana, padahal peserta didik membutuhkan penjelasan yang lebih banyak untuk memahami materi-materi tersebut.

Berdasarkan masalah yang dihadapi pendidik di lapangan dan hasil wawancara dengan guru sehubungan dengan pembelajaran ilmu pengetahuan Alam (IPA) terpadu di kelas V Sekolah Dasar (SD) yaitu sebagai berikut: Masih terdapat kesulitan bagi guru yang mengajar kelas V SD untuk membangun konsep pemecahan masalah di dalam proses pembelajaran. Hal ini dikarenakan guru hanya menggunakan buku pegangan milik pribadi dan buku pinjaman dari sekolah yang jumlahnya tidak memadai sesuai dengan jumlah siswa sehingga hal tersebut mengakibatkan terbatasnya penyampaian dan strategi pembelajaran yang dilakukan oleh guru.

Buku yang digunakan kurang menarik perhatian siswa, buku yang digunakan oleh siswa berisi materi yang terlalu panjang, gambar yang terdapat di dalam buku monoton, dan soal-soal terdiri dari pilihan ganda, dimana kebanyakan siswa hanya memilih tanpa berusaha untuk mencari jawaban oleh sebab itu siswa cenderung kurang termotivasi hal ini terlihat ketika peneliti mengadakan observasi ketika proses pembelajaran berlangsung banyak siswa yang tidak fokus di dalam proses belajar.

Sarana dan prasarana di SD Negeri 35 Kota Lubuklinggau sudah lengkap akan tetapi guru kurang optimal untuk menggunakannya, sehingga proses belajar mengajar cenderung monoton dengan strategi ceramah, tanya jawab dan pemberian tugas. Siswa kelas V, pada umunya mengatakan masih mengalami 
kesulitan dalam memahami materi IPA hal ini dikarenakan sistem organ adalah bagian yang terdapat di dalam tubuh yang tidak dapat dilihat langsung.

Analisis karakter peserta didik pada SD Negeri 35 Kota Lubuklinggau bahwa tingkat usianya antara 11-12 tahun.Kemampuan rata-rata peserta didik dalam katagori tingkat tinggi, sedang dan rendah, hal ini dilihat dari hasil belajar dalam satu semester. Untuk tingkat ekonomi rata-rata pekerjaan orangtua $50 \%$ buruh harian, $10 \%$ pegawai negeri, 10\% swasta, 30\% lainnya. Hasil pengamatan peneliti untuk kecakapan dasar yang dimiliki oleh peserta didik antara lain: (a) peserta didik mampu mengoperasikan komputer, (b) peserta didik dapat menyimpan data di komputer dan (c) peserta didik dapat mengetik serta mengedit data di komputer. Peserta didik menjadi lebih bersemangat jika proses pembelajaran dilaksanakan dengan menggunakan media komputer. Dengan banyaknya materi pelajaran yang perlu divisualisasikan, peserta didik merasa kesulitan untuk memahami materi pelajaran khususnya tanpa dibantu dengan bahan ajar yang tepat dan dapat memperjelas materi yang disampaikan serta dapat memotivasi peserta didik untuk belajar lebih aktif.

Dari hasil analisis kebutuhan di atas dapat disimpulkan bahwa dibutuhkan inovasi baru di dalam proses belajar mengajar sehingga membuat siswa lebih termotivasi di dalam proses pembelajaran mata pelajaran IPA. Berdasarkan pengamatan peneliti di lapangan peserta didik sangat antusias jika proses pembelajaran menggunakan teknologi komputer, hal ini dikarenakan peserta didik lebih termotivasi jika proses pembelajaran menggunakan teknologi komputer sehingga mereka bisa menyalurkan minat dan bakat mereka di dalam mengespresikan kemampuan teknologi yang mereka miliki, hal ini menjadi pertimbangan untuk peneliti agar membuat bahan ajar yang bisa digunakan oleh peserta didik dengan mengembangkan minat dan bakat mereka. Oleh karena itu peneliti akan mengembangkan Multimedia Interaktif pada Pelajaran IPA di SD Negeri 35 Kota Lubuklinggau.

Langkah kedua dalam pengembangan media pembelajaran ini adalah tahap pengembangan. Terdapat empat tahapan pada tahap pengembangan yaitu (1) jabaran materi, (2) garis besar isi media, (3) flowchart, flowchart ada tiga bagian yaitu flowchart pembuka, flowchart latihan dan flowchart evaluasi (4) hasil computer based desaign. GBIM terdiri dari satu standar kompetensi dan lima kompetensi dasar. Jabaran materi terdiri dari lima pokok bahasan untuk empat sesi pertemuan yang dikembangkan dari lima kompetensi dasar (Gustafson, Kent, dan Branch, M Robert. 2002).

Flowchart; Alur program dibuat mulai dari pembuka (start), isi disampaikan keluar program (exit). Adapun Multimedia Interaktif IPA dengan Pokok Bahasan Sistem Organ Pada Mahkluk Hidup yang dikembangkan terdiri dari tiga bagian yaitu: 1) Flowchart Pembuka terdiri dari beberapa menu yang terdiri dari start, opening, menu utama yang terdiri dari (petunjuk program, $\mathrm{SK} / \mathrm{KD}$, indikator, dengan memanfaatkan komputer untuk menggabungkan teks, grafik, animasi, audio, dan video, evaluasi dan penutup) dan menu materi; 2) Flowchart Latihanterdapat dalam menu materi. Pada materi memiliki latihan yang terdiri dari soal essay pada materi 1 sampai 3, materi 4 dan 5 berupa soal pilihan ganda berjumlah 10 soal. Soal latihan ini dibuat sesuai dengan materi yang ada dalam Multimedia Interaktif.Setiap user menjawab soal maka komputer langsung merespon apakah jawaban benar atau salah pada setiap soal yang dijawab. Setelah 
user menyelesaikan 10 soal tersebut, maka komputer akan memberikan hasil skor yang diperoleh user; 3) Flowchart Evaluasi terdapat pada menu utama.Pada soal evaluasi terdapat tugas mandiri. Soal evaluasi tidak sama dengan soal latihan. Apabila user menjawab benar ataupun salah maka akan terus lanjut ke soal berikutnya sampai dengan selesai.

Model Draft I, untuk pertama sekali Prototype Multimedia Interaktif dinilai oleh peneliti sendiri yang disebut Self Evaluation yang bertujuan meminimalisir kesalahan penulisan, materi, dan keserasian desain Multimedia Interaktif yang berkaitan dengan isi (content), desain (construct) dan media (layout) dari Prototype Multimedia Interaktif tersebut. Prototype Multimedia Interaktif yang dihasilkan menurut penilaian dirasa sudah cukup baik. Selanjutnya akan di validasi oleh expert review dan diujicobakan pada one to one evaluation untuk mengidentifikasi dan mengurangi kesalahan-kesalahan yang ada dalam Multimedia Interaktif tersebut. Sehingga Multimedia Interaktif yang dihasilkan praktis dan dapat digunakan oleh siswa.

Produk awal multimedia ini diawali dengan mendesain multimedia interaktif IPA dengan pokok bahasan Sistem Organ Pada Makhluk Hidup tersebut ke dalam bentuk computer based. Desain pembelajaran multimedia interaktif IPA dengan pokok bahasan Sistem Organ Pada Makhluk Hidup yang telah dibuat oleh peneliti dalam bentuk paper based diwujudkan dalam bentuk computer based yang terdiri dari pemprograman dasar, pembuatan grafis, pembuatan animasi, pembuatan narasi.

Program yang digunakan peneliti untuk mendesain Multimedia Interaktif dalam bentuk computer based adalah Macromedia Flash 8. Program ini dapat digunakan dalam perancangan perangkat lunak interaktif dengan navigasi dan desain yang sangat menarik.Sehingga dapat membantu keinginan peneliti dalam membuat multimedia interaktif IPA dengan pokok bahasan Sistem Organ Pada Makhluk Hidup.

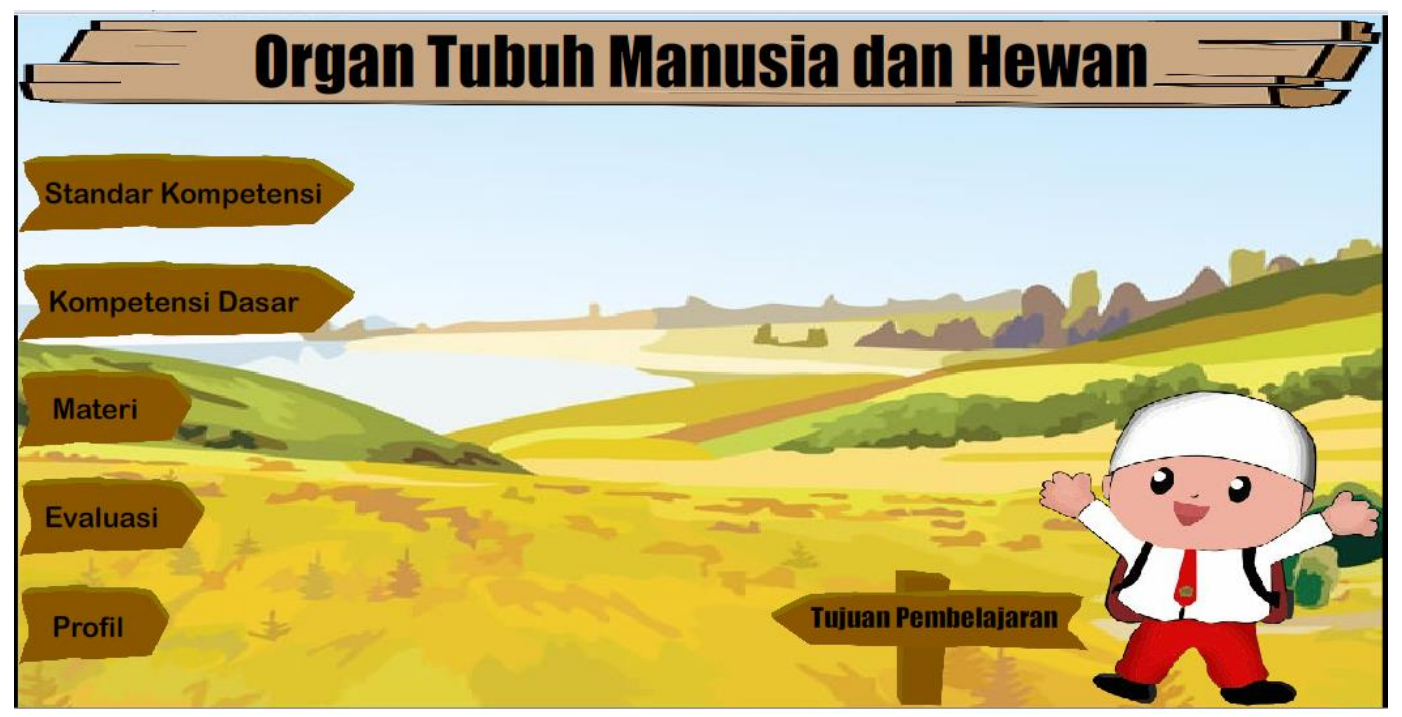

Gambar 5.1 Tampilan Awal Multimedia Interaktif

Gambar 5.1 merupakan tampilan awal pada multimedia interaktif pada pelajaran IPA Kelas V SD dalam pokok bahasan sistem organ pada makhluk 
hidup.Pada tampilan awal atau pembuka terdapat judul materi, standar kompetensi, kompetensi dasar, materi, evaluasi, tujuan pembelajaran dan profil peneliti.

Materi yang disajikan pada multimedia interaktif dapat dilihat pada Gambar 2 dan 3 di bawah ini.

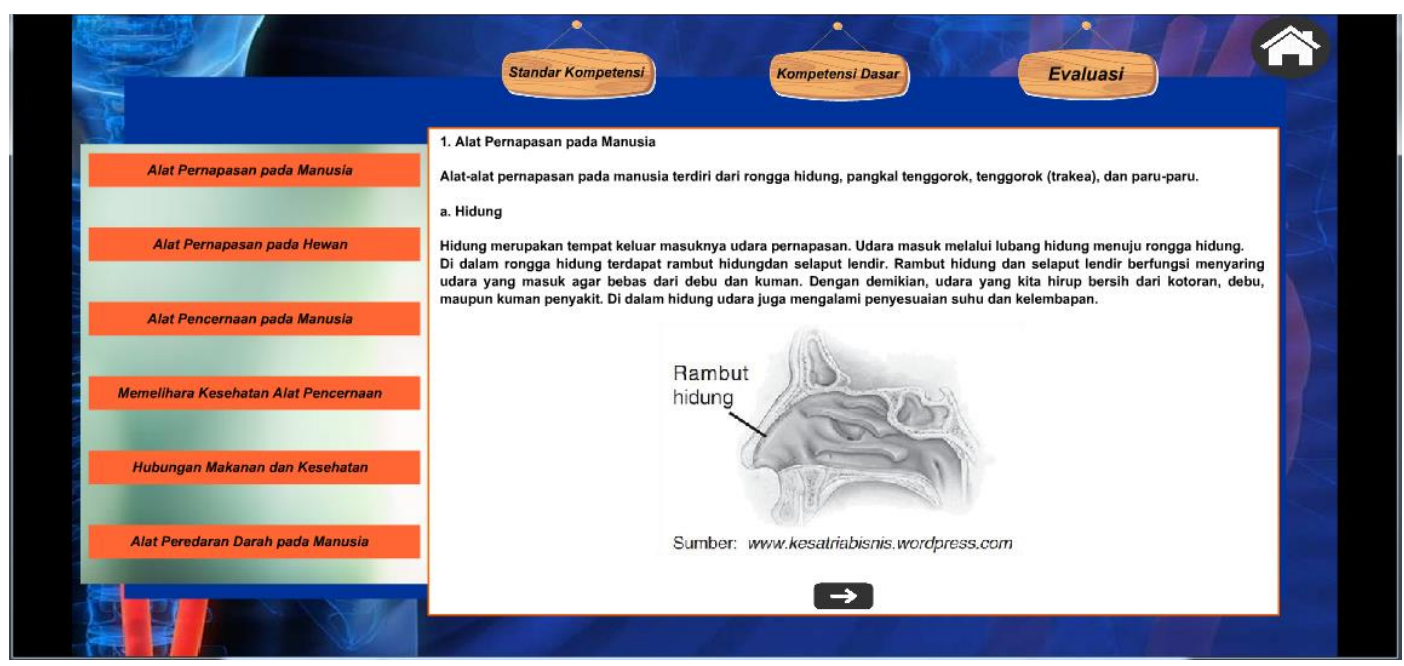

Gambar 2 Tampilan Isi Materi

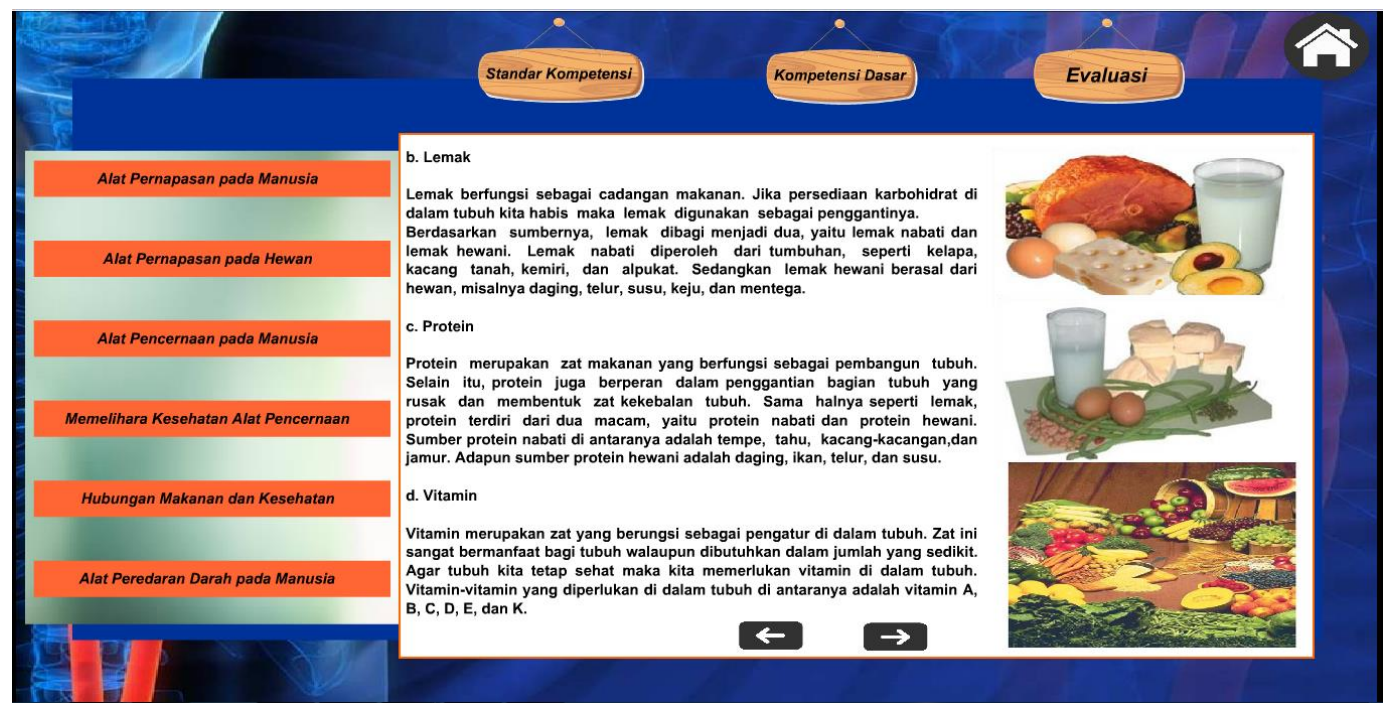

Gambar 3 Tampilan Gambar Materi

Gambar 2 dan 3 merupakan bagian dari materi pada multimedia interaktif berisi tulisan dan animasi tentang makanan dan kesehatan.

\section{Model Draft II}

\section{Hasil Validasi Materi IPA}

Model draft I multimedia interaktif diberikan kepada expert review tahap ini bertujuan untuk mendapatkan Multimedia Interaktif IPA yang valid. Dari hasil validasi ahli materi diperoleh saran berupa; materi masih perlu direvisi dan 
perlu dilengkapi lagi; pada penulisan (ejaan, huruf dan tanda baca) perlu diperhatikan; dan tingkat kesukaran soal harus disesuaikan.

Tabel 1

Hasil validasi ahli materi

\begin{tabular}{llll}
\hline Indikator & Penilaian & \\
\hline 1. & Uraian materi & Ya & Tidak \\
\hline 2. & $\begin{array}{l}\text { Kesesuaian materi dengan kompetensi yang harus dikuasai } \\
\text { peserta didik }\end{array}$ & $\mathrm{V}$ & \\
\hline 3. & Kesesuaian materi dengan RPP yang dibuat & $\mathrm{V}$ & \\
\hline 4. & Ketepatan / keakuratan materi & $\mathrm{V}$ & \\
\hline 5. & Kelengkapan materi & & $\mathrm{V}$ \\
\hline 6. & Kesesuaian bahan tes dengan bahan ajar & $\mathrm{V}$ & \\
\hline 7. & Tingkat kesukaran soal & & $\mathrm{V}$ \\
\hline 8. & $\begin{array}{l}\text { Kesuaian rangkuman, tugas, tes formatif dan kunci } \\
\text { jawaban tes formatif dengan materi }\end{array}$ & $\mathrm{V}$ & \\
\hline
\end{tabular}

Pada tabel 5.1 di atas terdapat delapan indikator yang dinilai oleh expert review bidang materi, penilaian yang diberikan pada setiap indikator adalah Ya yaitu indikator yang tertulis tersebut terdapat di dalam multimedia interaktif pada sistem organ mahkluk hidup yaitu; (1) Uraian materi, pada aspek ini uraian materi telah disesuaikan dengan materi sistem organ mahkluk hidup; (2) Kesesuaian materi dengan kompetensi yang harus dikuasai peserta didik, pada aspek ini materi telah sesuai dengan kompetensi; (3) Kesesuaian materi dengan RPP yang dibuat, pada aspek ini materi telah sesuai dengan RPP; (4) Ketepatan / keakuratan materi, (5) Kelengkapan materi, pada penyajian materi pada multimedia adanya tulisan, gambar, animasi dan video; (6) Kesesuaian bahan tes dengan bahan ajar, pada indikator ini tes yang dibuat disesuaikan dengan materi pelajaran; (7) Tingkat kesukaran soal, dan (8) Kesuaian rangkuman, tugas, tes formatif dan kunci jawaban tes formatif dengan materi.

Berdasarkan dari review, komentar dan saran dari expert review ahli materi dapat disimpulkan bahwa Multimedia Interaktif yang peneliti kembangkan valid dan dapat dapat digunakan.

\section{Hasil Validasi Ahli Media}

Model draft I multimedia interaktif juga divalidasi oleh ahli media. Expert review memberikan komentar dan saran sebagai berikut yaitu; pada latihan sebaiknya siswa mengetahui hasil latihan pada bagian mana yang masih harus diperbaiki, pada multimedia ini sebelumnya belum terdapat nilai atau skor yang diperoleh siswa jika telah menyelesaikan soal latihan; Soal latihan dapat diulang kembali hingga penguasaan siswa maksimal; Warna sumber dan teks harus kontras. 
Tabel 2

Hasil validasi ahli materi

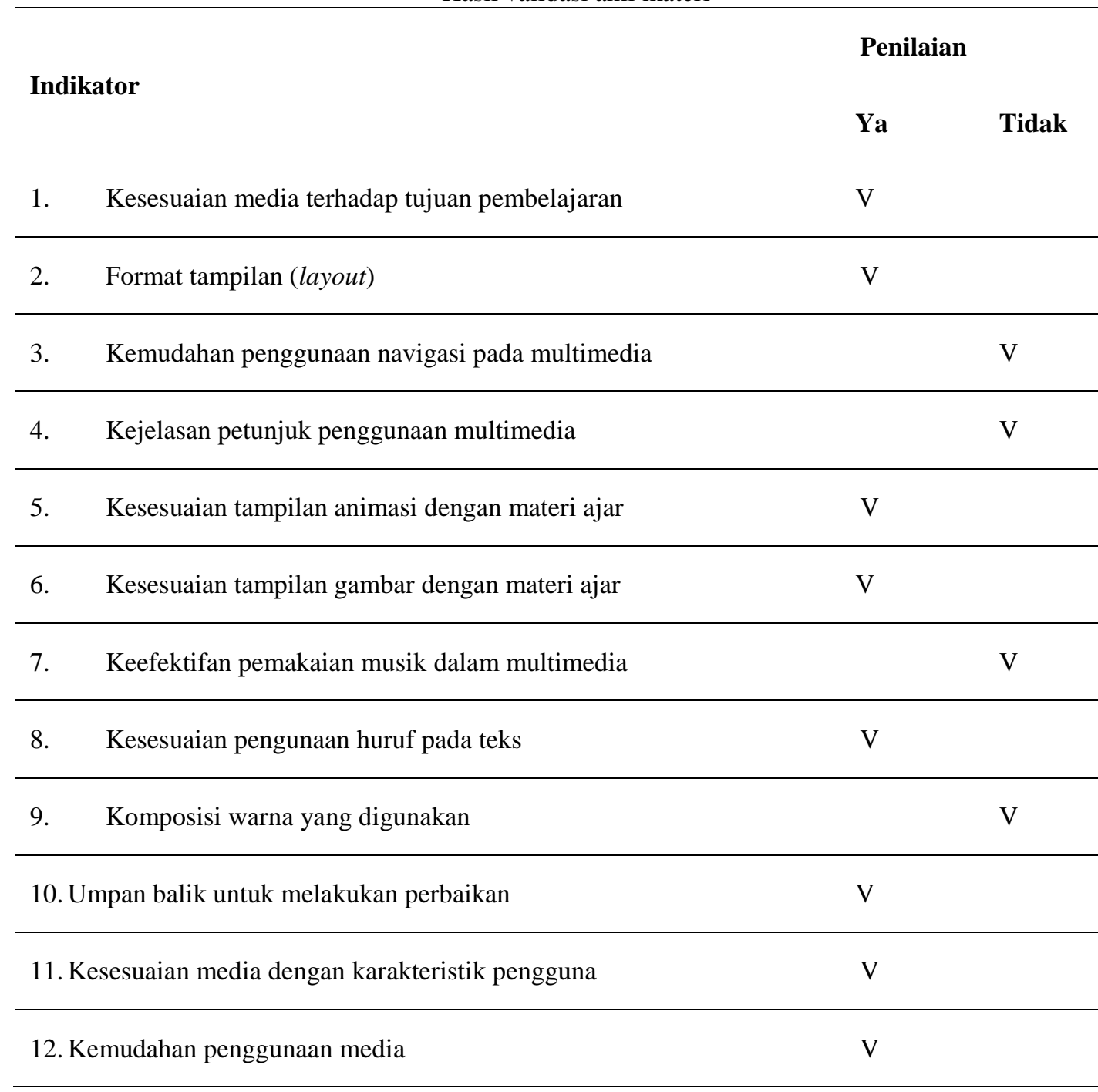

Pada tabel di atas terdapat delapan indikator yang dinilai oleh expert review bidang media, penilaian yang diberikan pada setiap indikator adalah Ya yaitu indikator yang tertulis tersebut terdapat di dalam multimedia interaktif pada sistem organ mahkluk hidup yaitu; (1) Kesesuaian media terhadap tujuan pembelajaran, pada aspek tujuan pembelajaran sesuai dengan media yang dibuat; dalam (2) Format tampilan (layout), pada aspek ini layout yang ada pada multimedia telah sesuai, dalam hal ini telah sesuai antara warna background dengan warna tulisan dan sudah kontras; (3) Kemudahan penggunaan navigasi pada Multimedia Interaktif, pada aspek ini penyajian navigasi belum sesuai dengan tampilan multimedia yang dibuat, sebab masih terdapat beberapa navigasi yang setelah di klik belum berfungsi dengan baik, sehingga perlu dilakukan revisi pada indikator ini; (4) Kejelasan petunjuk penggunaan Multimedia Interaktif, pada aspek ini petunjuk untuk menggunakan multimedia sudah sesuai, hanya terdapat kekurangan pada bahasa yang digunakan dalam petunjuk penggunaan belum menggunakan bahasa yang mudah dimengerti oleh user / siswa, oleh karena itu, 
perlu direvisi; (5) Kesesuaian tampilan animasi dengan materi ajar, pada indikator ini penyajian animasi sudah sesuai dengan materi, hal ini terlihat dari gambargambar animasi yang di tampilkan sudah sesuai dengan judul materi yang dibahas; (6) Kesesuaian tampilan gambar dengan materi ajar, penyajian gambar pada multimedia telah sesuai dengan materi sistem organ mahkluk hidup; (7) Keefektifan pemakaian musik dalam Multimedia Interaktif, pada penyajian musik belum dalam kategori efektif, sebab untuk penggunaan musik harus disesuaikan dengan siapa user/siswa yang menggunakan, berikan pilihan agar siswa dapat memilih volume suara yang mereka inginkan; (8) Kesesuaian penggunaan huruf pada teks, pada aspek ini penggunaan huruf dan teks telah sesuai dan mempermudah saat membaca materi; (9) Komposisi warna yang digunakan, komposisi warna yang digunakan telah disesuaikan dengan background multimedia dan teks harus kontras; (10) Umpan balik untuk melakukan perbaikan, dalam hal umpan balik ini adalah mengukur interaktif siswa. Umpan balik ini berupa latihan yang sebaiknya siswa mengetahui hasil latihan, dan pada bagian mana yang masih harus diperbaiki; (11) Kesesuaian media dengan karakteristik pengguna sudah ada, hal ini terlihat dari komponen-komponen dalam multimedia yang telah disesuaikan berdasarkan karakteristik user / siswa; (12) Kemudahan menggunakan media sudah ada, terlihat dari adanya petunjuk penggunaan multimedia yang memudahkan siswa untuk menggunakan multimedia interaktif.

\section{Hasil Validasi Desain Pembelajaran}

Model draft I multimedia interaktif diberikan kepada expert review tahap ini bertujuan untuk mendapatkan Multimedia Interaktif IPA yang valid. Dari hasil validasi ahli materi diperoleh komentar dan saran berupa; tampilan multimedia sudah baik dan interaktif, telah terdapat pengaturan suara yang bisa diatur secara manual, penambahan contoh gambar atau animasi di materi sistem organ hewan.

Berdasarkan data yang diperoleh dari ahli desain, dapat dideskripsikan sebagai berikut; (1) pada aspek isi materi pembelajaran sudah baik, sebab informasi yang disampaikan dalam multimedia interaktif terlebih dahulu dilakukan analisis kebutuhan siswa berupa materi-materi pelajaran yang sudah dipahami dan belum dipahami oleh siswa; (2) kualitas teknis seperti suara dan video animasi yang terdapat pada multimedia sudah baik, sebab multimedia interaktif berupa prototype telah dilakukan uji validasi media, yang salah satu indikatornya keefektifan suara yang sudah baik; (3) instalasi multimedia mudah dipasang, karena multimedia interaktif dapat disimpan di komputer dan di dalam flashdisk; (4) akurasi teknis seperti isi materi multimedia tepat dengan pelajaran IPA sistem organ sudah sangat baik, multimedia yang dibuat terdapat gambar dan animasi yang disesuaikan dengan kajian materi yang di bahas; (5) dasar-dasar pembelajaran pada multimedia ini telah mengidentifikasi sasaran yang akan dicapai dengan sangat baik, berdasarkan tujuan pembelajaran dan jabaran materi; (6) Pada aspek identifikasi sasaran sangat baik karena telah terdapat petunjuk untuk menggunakan secara efektif. Petunjuk penggunaan memudahkan user / siswa dalam menggunakan multimedia interaktif; (7) tujuan pembelajaran pada multimedia ini telah menyajikan tujuan pembelajaran, yang didapat melalui analisis kebutuhan; (8) strategi pembelajaran dinilai oleh validator sudah baik, dalam hal ini validator adalah expert atau ahli di bidangnya masing-masing dan 
telah berpengalaman; (9) nuansa pada multimedia ini baik penyajian pembelajaran yang jelas, tepat sasaran untuk siswa kelas $\mathrm{V}$, dan simbol-simbol yang ada pada multimedia jelas dan mudah digunakan; (10) motivasi: pada multimedia melibatkan langsung siswa dalam latihan dan tes, menarik minat dan semangat melalui media audio dan video animasi; (11) pengujian hasil belajar: latihan dan tes yang terdapat pada multimedia dinilai validator sudah baik. Pengujian hasil belajar merupakan usaha timbal balik dengan siswa; (12) informasi pendukung; (13) Pada aspek pencatatan dinilai sudah baik oleh validator; (14) tingkat kreativitas multimedia baik, dalam multimedia terdapat kombinasi media pembelajaran seperti teks, gambar klip audio, dan video animasi, yang di dapat dari Garis Besar Isi Media (GBIM); (15) pada bagian navigasi sudah baik hal ini terlihat dari urutan-urutan dalam multimedia yang dapat memudah user / siswa dalam menggunakannya dan (16) estetika penilaian yang diberikan validator adalah baik; (17) pemanfaatan media seperti media musik, narasi, efek suara dan media video dipilih tepat dan efektif, sesuai dengan analisi kebutuhan dan analisis karakteristik siswa.

\section{Model Draft III \\ One to One Evaluation}

Produk yang telah diperbaiki berdasarkan hasil validasi ahli materi, ahli media dan ahli desain pembelajaran selanjutnya akan digunakan untuk uji coba kelompok kecil. Pada uji coba one to one evaluation ini, instrument pengumpulan data berupa lembar wawancara.

Wawancara dilakukan kepada siswa untuk memperoleh tanggapan siswa terhadap prototype multimedia interaktif IPA dengan pokok bahasan Sistem Organ Pada Mahkluk Hidup yang bertujuan untuk memperoleh masukan dan komentar siswa terhadap Prototype Multimedia Interaktif.

Tabel 3

Komentar dan Saran Peserta didik Pada Tahap One to One

\begin{tabular}{|c|c|c|c|c|}
\hline No & $\begin{array}{l}\text { Nama Peserta } \\
\text { Didik }\end{array}$ & Kelas & Komentar dan Saran & $\begin{array}{l}\text { Tanggapan } \\
\text { peneliti }\end{array}$ \\
\hline 1 & $\begin{array}{l}\text { BJ } \\
\text { Siswa mewakili } \\
\text { kelompok rendah }\end{array}$ & V & $\begin{array}{l}\text { Materi yang ada di dalam } \\
\text { Multimedia Interaktif sangat mudah } \\
\text { sekali di pahami, gambar dan } \\
\text { animasinya sangat menarik }\end{array}$ & $\begin{array}{l}\text { Diterima } \\
\text { komentar dan } \\
\text { sarannya }\end{array}$ \\
\hline 2 & $\begin{array}{l}\text { KY } \\
\text { Siswa mewakili } \\
\text { kelompok sedang }\end{array}$ & V & $\begin{array}{l}\text { Materi yang ada di dalam } \\
\text { Multimedia Interaktif sangat } \\
\text { lengkap dan jelas, gambar dan } \\
\text { animasi sangat sesuai karena } \\
\text { berhubungan dengan materi yang } \\
\text { ada di dalam Multimedia Interaktif }\end{array}$ & $\begin{array}{l}\text { Diterima } \\
\text { komentar dan } \\
\text { sarannya }\end{array}$ \\
\hline 3 & $\begin{array}{l}\text { LA } \\
\text { Siswa mewakili } \\
\text { kelompok tinggi }\end{array}$ & V & $\begin{array}{l}\text { Gambar dan animasi menarik } \\
\text { mudah untuk belajar. }\end{array}$ & $\begin{array}{l}\text { Diterima } \\
\text { komentar dan } \\
\text { sarannya }\end{array}$ \\
\hline
\end{tabular}


Berdasarkan hasil one to one evaluation dan observasi langsung dengan tiga siswa terlihat siswa BJ, KY dan LA mengalami kemudahan dalam menggunakan multimedia interaktif, siswa tersebut cepat mengerti cara mengoperasikan tiap-tiap bagian yang ada di multimedia, pemahaman dalam materi yang tadinya bersifat abstrak kini jadi lebih dapat divisualisai siswa dengan melihat gambar animasi dan video secara langsung, gambar dan animasi yang menarik membuat siswa tersebut lebih tertarik dalam mempelajari tiap materi.

\section{Small Group Evaluation}

Berdasarkan dari hasil expert review dari kesulitan yang dialami guru dan siswa (one to one evaluation) pada saat uji coba pada prototype pertama dijadikan dasar untuk merevisi prototype pertama menjadi prototype kedua, kemudian diujicobakan pada small group yaitu pemberian multimedia interaktif IPA pokok bahasan Sistem Organ Pada Mahkluk Hidup yang telah direvisi (prototype kedua) kepada delapan orang siswa Sekolah Dasar Negeri 35 yang tidak ikut uji coba one to one evaluation.

\section{PEMBAHASAN}

\section{Hasil Validitas Multimedia Interaktif IPA}

Untuk validitas desain pembelajaran adalah bapak Dodik Mulyono, M.Pd, Dosen program studi Pendidikan Matematika, STKIP-PGRI Lubuklinggau, memberikan saran, komentar, dan memberikan penilaian untuk desain pembelajaran dengan kategori valid. Validitas isi (content) sebagai validator adalah bapak Zico Fachrurozi, M. Pd., Dosen Pendidikan Biologi STKIP-PGRI Lubuklinggau yang memberikan penilaian terhadap content ini valid.Selanjutnya media (layout) sebagai validator adalah Dian Samitra, M. Pd. yaitu Dosen Pendidikan Biologi yang penilaian terhadap media (layout) yaitu kategorinya adalah valid.

Dengan demikian multimedia interaktif IPA dengan pokok bahasan Sistem Organ Pada Mahkluk Hidup dinyatakan valid dan dapat digunakan karena telah saling berkesinambungan antara komponen yang satu dengan komponen yang lain.

\section{Hasil Praktikalitas Multimedia Interaktif IPA}

Praktikalitas artinya Multimedia Interaktif IPA tersebut dapat dilaksanakan, mudah penggunaannya dan dapat digunakan. Untuk mengetahui Multimedia Interaktif IPA tersebut dapat dilaksanakan ini praktis dapat dilaksanakan peneliti melakukan pengujian terhadap 3 orang siswa (one to one evaluation), dimana siswa yang digunakan memiliki karakteristik rendah, sedang dan tinggi. Mereka diminta untuk memberikan tanggapan terhadap desain produk berupa Multimedia Interaktif IPA. Hasil komentar peserta didik akan digunakan untuk merevisi desain Multimedia Interaktif IPA dapat dilaksanakan yang telah dibuat.

Setelah pengujian one to one evaluation selesai, peneliti melakukan pengujian terhadap delapan orang siswa yang disebut dengan small group evaluation.Padasmall group evaluation ini, pembelajaran diberikan dalam satu kelas yang sama di mana pembelajaran tersebut akan digunakan dalam kondisi yang sebenarnya. 
Berdasarkan hasilsmall group evaluation tersebut, peneliti akan mencatat bagaimana peserta didik melakukan proses pembelajaran dengan menggunakan. Multimedia Interaktif IPA tersebut yang sedang dikembangkan. Selanjutnya mereka memberikan tanggapan terhadap prototype pertama yang dihasilkan melalui kuesioner mengenai tanggapan peserta didik terhadap Multimedia Interaktif IPA.

Berdasarkan hasil dari tanggapan peserta didik sebesar $86 \%$ dengan kategori bahwa Multimedia Interaktif IPA ini praktis digunakan. Multimedia Interaktif IPA yang praktis merupakan Multimedia Interaktif IPA dapat digunakan dan dimanfaatkan oleh siswa. hal ini diperkuat oleh Pribadi (2009 : 122), memanfaatkan bahan pembelajaran perlu dilakukan secara optimal, agar guru dan instruktur dapat membantu siswa dalam mencapai kompetensi, guru dan instruktur diharapkan mampu secara kreatif menciptakan kombinasi pemanfaatan metode dan materi pembelajaran yang dapat berfungsi dalam mencari pembelajaran sukses.

\section{Hasil Efek Potensial Multimedia Interaktif IPA Terhadap Hasil Belajar Siswa}

Berdasarkan hasil uji coba ke subjek penelitian sesungguhnya yaitu 30 orang peserta didik kelas $\mathrm{V}$, menunjukkan bahwa prototype ketiga memiliki efek potensial untuk digunakan pada pembelajaran IPA. Hal ini terlihat selama kegiatan pembelajaran berlangsung tidak terjadi hambatan yang begitu berarti dengan kata lain pembelajaran berlangsung efektif. Hanya saja ketika awal kegiatan perlu melakukan sedikit adaptasi yang selama ini secara manual khususnya mata pelajaran IPA tetapi beberapa menit kemudian peserta didik mulai terbiasa terlihat dari semangat mereka mempelajari materi tersebut melalui Multimedia Interaktif.Bila dilihat dari hasil belajar peserta didik dalam kegiatan pembelajaran setelah diperlakukan dengan menggunakan Multimedia Interaktif IPA yang dikembangkan didapat hasil belajar dengan angka rata-rata 79,11 atau < nilai 70 (KKM) 6 peserta didik dalam kategori sangat tinggi, 16 peserta didik dalam kategori tinggi dan 5 peserta didik dengan kategori sedang. Hal ini menunjukkan bahwa efek potensial dari Multimedia Interaktif IPA terhadap hasil belajar peserta didik dengan persentase ketuntasan belajar 77\%. Maka dari itu, Multimedia Interaktif IPA tersebut dapat digunakan oleh siswa.Dengan demikian, produk Multimedia Interaktif IPA yang peneliti kembangkan memiliki efek potensial ketika digunakan dalam kegiatan pembelajaran IPA di kelas V bagi Sekolah Dasar Kota Lubuklinggau.

Adapun kesimpulan ini sejalan dengan pendapat Sanjaya (2010: 168) bahwa bahan ajar dapat meningkatkan dan mengarahkan perhatian siswa sehingga dapat menimbulkan ketertarikan, minat, dan motivasi untuk mengikuti proses pembelajaran. 


\section{KESIMPULAN}

Berdasarkan hasil penelitian yang telah dilakukan, maka dapat disimpulkan bahwa multimedia Interaktif Pada Pelajaran IPA Bagi Siswa Sekolah Dasar Kota Lubuklinggau dinyatakan valid oleh ahli materi, ahli desain, dan ahli media. Sehingga layak digunakan dalam pembelajaran IPA. Multimedia Interaktif Pada Pelajaran IPA Bagi Siswa Sekolah Dasar Kota Lubuklinggau dinyatakan praktis setelah diujicobakan kepada peserta didik. Praktikalitas telah diujicobakan secara one-to-one dan small group, sehingga layak digunakan dalam pembelajaran IPA.

Berdasarkan hasil analisis nilai tes (pretest dan posttest) pada tahap field test diperoleh ketuntasan hasil belajar sebesar 77\%. Hasil ini menunjukkan bahwa Multimedia Interaktif Pada Pelajaran IPA Bagi Siswa Sekolah Dasar Kota Lubuklinggau mempunyai efek potensial yang positif terhadap hasil belajar peserta didik. 


\section{DAFTAR PUSTAKA}

Arsyad, A. (2009). Media Pembelajaran, Jakarta : PT Raja Grafindo Persada.

B.R. Seels. (2009). Teknologi Pembelajaran. Jakarta: Penerbit Universitas Negeri Jakarta.

Campbell, R \& Mitchell. (2000). Biologi, Edisi Kelima. Jakarta: Penerbit Erlangga.

Fathan, F. (2011). Peranan Multimedia Interaktif pada Pembelajaran Kesetimbangan.

Gustafson, K, \& Branch, M.,R. (2002). Survey of Instructional Development ModelsNew York: Fourth editions. Syracuse.

Martin, T. (1993). Planning and Conducting Formative Evaluations: Improving The Quality of Education and Training. London: Kogan Page.

Nasution. (2011). Metode Research Penelitian ilmiah. Jakarta: Bumi aksara.

Pribadi, B. (2009). Model Desain Sistem Pembelajaran.Jakarta: Dian Rakyat.

Pujawan, K.,A.,H. (2000). Pengembangan Multimedia Interaktif Pembelajaran Animasi berbasis

Setiawan, D.(2001). Pengembanga Bahan Ajar.Jakarta: UT.

Uno.H. (2011). Model Pembelajaran. Jakarta: Bumi Aksara. 